\title{
Fanconi anemia and the cell cycle: new perspectives on aneuploidy Grzegorz Nalepa $^{1-3 *}$ and D. Wade Clapp ${ }^{1,3-5 *}$
}

Addresses: ${ }^{1}$ Department of Pediatrics, ${ }^{2}$ Division of Pediatric Hematology-Oncology, Indiana University School of Medicine, Riley Hospital for Children, 705 Riley Hospital Drive, Indianapolis, IN 46202, USA; ${ }^{3}$ Department of Medical and Molecular Genetics, ${ }^{4}$ Department of Microbiology and Immunology, ${ }^{5}$ Department of Biochemistry and Molecular Biology, Wells Center for Pediatric Research, 1044 W. Walnut Street, Indiana University School of Medicine, Indianapolis, IN 46202, USA

*Corresponding authors: Grzegorz Nalepa (gnalepa@iu.edu); D. Wade Clapp (dclapp@iu.edu)

Fl000Prime Reports 2014, 6:23 (doi:10.12703/P6-23)

All FI000Prime Reports articles are distributed under the terms of the Creative Commons Attribution-Non Commercial License (http:/l creativecommons.org/licenses/by-nc/3.0/legalcode), which permits non-commercial use, distribution, and reproduction in any medium, provided the original work is properly cited.

The electronic version of this article is the complete one and can be found at: http://f1000.com/prime/reports/m/6/23

\begin{abstract}
Fanconi anemia (FA) is a complex heterogenic disorder of genomic instability, bone marrow failure, cancer predisposition, and congenital malformations. The FA signaling network orchestrates the DNA damage recognition and repair in interphase as well as proper execution of mitosis. Loss of FA signaling causes chromosome instability by weakening the spindle assembly checkpoint, disrupting centrosome maintenance, disturbing resolution of ultrafine anaphase bridges, and dysregulating cytokinesis. Thus, the FA genes function as guardians of genome stability throughout the cell cycle. This review discusses recent advances in diagnosis and clinical management of Fanconi anemia and presents the new insights into the origins of genomic instability in FA. These new discoveries may facilitate the development of rational therapeutic strategies for FA and for FA-deficient malignancies in the general population.
\end{abstract}

Fanconi anemia: a disorder of genomic instability FA is a group of genetic syndromes associated with bone marrow failure, congenital abnormalities, hypersensitivity to DNA-damaging agents, and a high cancer risk [1-5]. Few congenital disorders are as genetically and clinically complex as FA. We currently know at least 16 human FA genes (FANCA through FANCQ), and more FA genes remain to be discovered [6-8].

Translational and basic research continues to shed new light on the mechanisms of carcinogenesis resulting from disruption of FA signaling. The genomic instability in FA results from impaired interphase DNA damage repair as well as from error-prone chromosome segregation during mitosis. Thus, we propose that FA signaling functions as a guardian of the genome throughout the cell cycle.

Here we provide a brief overview of clinical aspects of FA, followed by a discussion of new discoveries regarding the pathophysiology of FA. We hope these new findings will open new inroads to rational targeted therapies in FA.

\section{Diagnostic and therapeutic challenges}

The prevalence of FA is grossly estimated at 10 cases per 1 million individuals [9]. The median age of diagnosis is 7 years of age [10], but FA may remain unrecognized until adulthood due to the high clinical heterogeneity of this disease [11-13]. Developmental abnormalities seen in FA include short stature, muskuloskeletal malformations, such as deformities of thumbs and radii, café-au-lait spots, structural kidney and genitourinary tract defects, and VACTERL (Vertebral anomalies, Anal atresia, Cardiac defects, Tracheoesophageal fistula and/or Esophageal atresia, Renal anomalies, and Limb defects) association [14]. Importantly, at least one in three FA patients does not have any visible malformations $[15,16]$. Thus, diagnosis of FA requires a high clinical index of suspicion [16].

Progressive bone marrow failure is the consistent clinical hallmark of FA. Gradual depletion of bone marrow stem cells impairs hematopoiesis. Decreased blood counts lead to symptoms that often appear in the first decade of life but may remain undetected for much longer because of their insidious onset. These symptoms include malaise 
and pallor due to anemia, bruising and bleeding due to low platelet counts, and infections due to falling neutrophil counts. This clinical scenario requires a bone marrow aspirate to exclude leukemia. In most FA patients, bone marrow analysis reveals decreased hematopoiesis but no malignancy. If the blood counts do not recover within 1-2 months, a chromosome breakage test to exclude FA is indicated. This test is based on the fact that exposure to low-dose DNA-crosslinking chemotherapeutics such as diepoxybutane (DEB) [17] causes chromosome fragmentation in living FA patient cells but not in normal cells. A positive DEB test is followed by candidate FA gene sequencing, which allows family counseling and helps personalize patient care as the genotype-phenotype correlations in FA are beginning to emerge [15].

FA is associated with a high risk of cancer: at least $20 \%$ FA patients will suffer from a malignancy during their lifetime $[1,4,18]$. The most common cancers in FA patients are acute myeloid leukemias (AMLs) followed by squamous cell carcinomas as well as brain and soft tissue tumors. While more studies are needed, the affected FA gene and the type of mutation appear to correlate with disease severity. Biallelic loss-of-function mutations of the well-known breast cancer susceptibility gene (FANCD1/BRCA2 [19]) are associated with severe FA that includes predisposition to childhood brain tumors and other solid tumors in addition to early onset of bone marrow failure and hematopoietic malignancies [20-23]. This particular observation provides clinical evidence of the functional link between the FA signaling and the breast cancer susceptibility pathways (reviewed in [24]).

Clinical management of FA patients requires multidisciplinary expertise. For young FA children with asymptomatic pancytopenia, close observation may be appropriate. In some FA patients with worsening bone marrow failure, anabolic androgens can improve blood counts [25], although this strategy may be associated with significant morbidities [26]. Severe bone marrow failure requires a stem cell transplant. The choice of preparative regimen is a matter of ongoing debate $[27,28]$. For FA patients, modern stem cell transplant strategies based on low-dose preparative regimens are well tolerated and lead to promising outcomes.

The risk of AML in FA appears to steadily increase after 10 years of age in patients who have not undergone a stem cell transplant. Treatment of AML in FA requires the use of modified chemotherapy and stem cell transplant to maximize the chance of cure. Adolescent FA patients face a high risk of developing squamous cell carcinomas (SCCs) $[29,30]$. The etiology of increased risk of SCC in FA is unclear. In 2005, it was reported that stem cell transplant increases the risk of SCCs in FA [31], but it is not known whether this risk is associated with modern stem cell transplant regimens. The role of HPV (human papillomavirus) had been implicated, but the studies aimed to detect HPV in FA-associated SCCs have generated conflicting results $[32,33]$. Since the SCCs in FA patients are very difficult to treat, a close surveillance followed by prompt surgical resection of suspicious lesions is essential.

Most FA patients experience medical issues throughout life, including endocrine abnormalities $[34,35]$ as well as therapy-related morbidities. As with other rare chronic illnesses, FA causes significant psychological stress to the family and the patient $[36,37]$. Therefore, the importance of psychological help cannot be underestimated.

Gene therapy for FA-associated bone marrow failure may become available in the future. Although early attempts at FA gene therapy were hampered by difficulties with engraftment of corrected cells [38], several groups have successfully used gene therapy in mouse models of FA $[39,40]$, and human clinical trials are anticipated soon $[41,42]$. We hope that better understanding of the origins of genomic instability in FA will allow rational development of targeted therapies.

\section{Fanconi anemia: genome surveillance throughout the cell cycle The canonical Fanconi anemia DNA damage response pathway in interphase}

All known FA proteins work in concert to control the DNA damage response (Fig. 1). Disrupted chromatin activates a network of kinases (including ATR and CHK1) to engage DNA damage pathways and arrest the cell cycle until the lesions are removed from the genome [43]. Some FA proteins are essential for this initial step in damage signal transduction: FANCM activates ATR [44] and CHK1 [45], and FANCJ promotes ATR-mediated cell cycle checkpoint signaling [46]. In return, ATR and CHK1 phosphorylate FANCA, FANCE, and FANCM [47-50]. This positive feedback loop connects the DNA damage kinases and FA proteins to amplify the DNA damage recognition signal. This in turn promotes the activation and assembly of the multiprotein FA core complex, which consists of eight FA proteins as well as several accessory proteins $[51,52]$.

Next, assembly of the core complex promotes monoubiquitination and activation of a FANCD2/FANCI heterodimer by the FANCL ubiquitin ligase [53,54]. Notably, phosphorylation of both FANCI $[47,55]$ and FANCD2 [56] by the DNA damage kinases is essential for the FANCD2/ FANCI monoubiquitination, again highlighting the complex interplay between the DNA damage kinases and Fanconi proteins. 
Figure I. Fanconi anemia (FA) signaling is essential for DNA damage repair in interphase

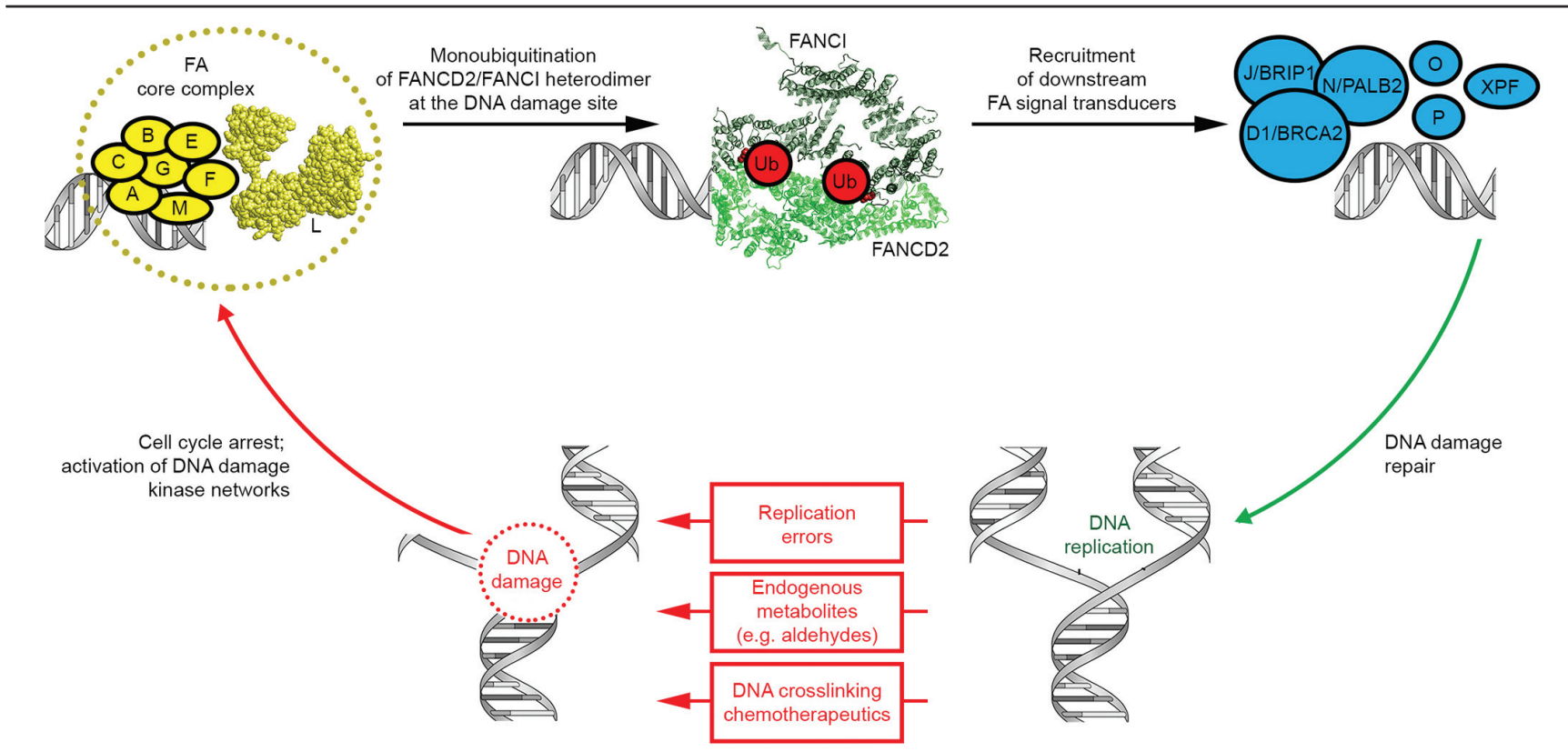

DNA damage in interphase due to genotoxic stress stimulates the DNA damage kinase network, which triggers assembly of the FA core complex followed by monoubiquitination of the FANCD2/FANCI heterodimer and activation of DNA damage repair processes. Abbreviations: Ub, ubiquitination.

Phosphorylation and monoubiquitination of the FANCD2/FANCI heterodimer activate the DNA repair pathways. A group of FA proteins responsible for this step is remarkable for several signal transducers that connect the breast cancer susceptibility pathways with the FA signaling. BRCA2, also known as FANCD1, is the most known gene that causes FA when both alleles are mutated and is associated with breast cancer risk when one allele is disrupted. At least three other genes (FANCN/PALB2, FANCJ/BRIP1, and FANCO/RAD51C) appear to follow a similar pattern of inheritance $[23,24,57-61]$. The clinical heterogeneity of the Fanconi phenotypes seems at least partially due to the divergence of gene-specific downstream signaling pathways.

The FA signaling pathway selectively activates the highfidelity homologous recombination-based damage repair, which is a default choice especially during the DNA replication [62]. FA-deficient cells attempt to repair the lesions through error-prone non-homologous end joining (NHEJ). Interestingly, the observation that silencing the NHEJ pathway alleviates DNA repair defects in some FA-deficient cells [63] suggests that increased mutagenesis in FA is at least partially due to the overuse of the NHEJ-based DNA repair.

It is not entirely clear how the FA signaling is turned off upon completion of the DNA damage repair, but recent work showed the critical role for the USP1 complex that deubiquitinates the FANDC2/FANCI heterodimer $[64,65]$. USP1 itself is downregulated by the DNA damage [65], providing another feedback loop to facilitate accumulation of the monoubiquitinated FANCD2/ FANCI heterodimer in injured cells. Interestingly, Usp1deficient mice display a phenotype similar to FA [66]. This observation implies that the ability to cycle the FA pathway on and off is essential to maintain the functionality of the FA signaling.

\section{The origins of DNA damage in Fanconi anemia-deficient cells}

The FA signaling pathway is essential to alleviate the mutagenic impact of a wide range of genotoxic insults, from chemotherapeutics [67] to ionizing radiation [68]. However, until recently, we did not know why FA patients develop genomic instability, even though most of them are not exposed to chemotherapy or radiation. New evidence indicates that genomic instability in FA is due to a combination of abnormal cell cycle progression and hypersensitivity to normal metabolic by-products such as aldehydes.

\section{Replication hazards: Fanconi anemia and the S-phase checkpoint}

DNA replication carries an intrinsic risk of DNA damage. Replication-associated DNA breaks are caused 
by topological stress induced by unwinding of chromatin fibers tethered to the nuclear matrix and by collisions between the DNA polymerases and the RNA transcription machineries $[69,70]$. In the presence of DNA crosslinks, the double helix cannot be unwound, and the replication forks stall to repair the crosslink before the replication continues. The S-phase checkpoint ensures stability of replication forks and relieves the effect of replication stress on the genome [71,72]. Notably, the same kinases that control the FA signaling during DNA damage response (e.g. ATR, CHK1) are essential for the S-phase checkpoint [73]. Thus, it is not surprising that the FA signaling is essential for the intra-S-phase checkpoint triggered by DNA interstrand crosslinks $[74,75]$.

\section{The pain of living: Fanconi anemia signaling alleviates metabolic collateral damage to the genome}

We are constantly bombarded by toxic molecules that are either required for our metabolism (oxygen) or generated as metabolic by-products (such as aldehydes). FA signaling protects our genomes from harmful effects of normal life processes.

The hypersensitivity of FA-deficient cells to oxidative stress is well known $[76,77]$. Recent studies revealed that the FA signaling provides a functionally important shield against the DNA damage induced by endogenous aldehydes. Since aldehyde metabolism may be amenable to small-molecule manipulation [78,79], this finding may provide future opportunities to decrease DNA damage and functional depletion of bone marrow cells in FA patients.

Aldehydes are highly reactive, carcinogenic molecules generated through metabolism of multiple chemicals, including alcohols [80]. FA-deficient chicken cells are hypersensitive to aldehyde-induced DNA damage [81]. To examine the potential role of endogenous aldehydeinduced DNA damage in FA-associated bone marrow failure and cancer, Langevin et al. disrupted the aldehyde detoxification pathway in Fancd2 ${ }^{-/-}$mice by knocking out the Aldh 2 aldehyde dehydrogenase. The Fancd $2^{-/-}$mice are prone to developmental defects and epithelial cancers [82] but do not spontaneously develop leukemia, although their bone marrow stem cells have mild baseline proliferation defects [83]. However, the double-knockout Fancd2 $2^{-/}$ Aldh $2^{-/-}$mice accumulate hematopoietic stem cell mutations [84]. These mice tend to die of acute leukemias early in life [82], and a small fraction of surviving leukemia-free Fancd ${ }^{-/-}$Aldh2 $2^{-/-}$mice develop bone marrow aplasia at a later age [84]. Interestingly, this sequence of events is reversed compared with humans with FA, who develop bone marrow failure before the onset of leukemia. More work is needed to evaluate the contribution of endogenous aldehydes to genomic instability in FA patients and to evaluate activation of aldehyde detoxification as a therapeutic strategy. Nevertheless, it is prudent to advise FA patients to avoid alcohol as it is metabolized to aldehydes.

\section{Division sickness: Fanconi anemia signaling prevents aneuploidy by regulating mitosis}

Abnormal chromosome segregation during cell division leads to gross genomic instability and aneuploidy, which are both a cause and consequence of cancer [85]. Cell cycle checkpoints prevent chaotic chromosome segregation in mitosis. The spindle assembly checkpoint (SAC) arrests cell division until all chromosomes are captured by the mitotic spindle microtubules [86]. Weakened spindle checkpoint increases the risk of random chromosome segregation, aneuploidy, and cancer. Not surprisingly, many SAC regulators are tumor suppressors [86].

We recently showed that disruption of FA signaling weakens the SAC, and we visualized multiple FA proteins on the mitotic spindle and centrosomes [87]. This connection between the FA signaling and the SAC helps us understand the origins of gross chromosomal instability in FA and sheds new light on the previously reported biochemical interactions between FA proteins and the key SAC regulators, such as the CDC2 cyclin-dependent kinase $[88,89]$. Efforts are under way to identify FA-regulated branches of the highly complex SAC signaling network. Since multiple SAC regulators are amenable to smallmolecule targeting, we expect that dissecting the links between the FA signaling and the spindle assembly checkpoint may reveal new therapeutic targets in FA-deficient cancers - both in FA patients and in the general population.

Recent work has shown that multiple FA proteins associate with centrosomes during mitosis to control centrosome function and physically interact with regulators of centrosome maintenance [90-92]. FA-deficient cells cannot maintain normal centrosome numbers under normal conditions [87,92-95] and upon exposure to DNA crosslinking agents [91]. While the essential role of FANCD1/ BRCA2 in centrosome maintenance and mitosis is well established [21,94,95], these new findings reveal the essential role of the entire FA signaling network in ensuring genome stability during mitosis. The presence of supernumerary centrosomes further disrupts chromosome segregation through abnormal kinetochore-spindle interactions [96]; therefore, we hypothesize that centrosome dysfunction further worsens genomic instability in FA-deficient cells through abnormal chromosome segregation. The key FA-dependent signaling pathways responsible for centrosome maintenance and high-fidelity 
execution of mitosis remain unknown, although the pololike kinase 1 (PLK1) was implicated in FA-dependent centrosome replication under genotoxic stress [91] and the never-in-mitosis-gene A (NIMA)-related kinase 2 (NEK2)dependent phosphorylation of FANCA was proposed to regulate baseline centrosome replication [92]. Seamless execution of later stages of mitosis also depends on the functional FA pathway. Some FA proteins resolve entangled DNA during mitosis by associating with anaphase bridges in collaboration with the BLM signaling pathway $[97,98]$. Finally, FA-deficient cells undergo abnormal cytokinesis [99], which further impairs chromosome segregation at the exit from mitosis.

Together, these data reveal that the FA signaling prevents genome instability through ensuring DNA damage repair in interphase and normal progression through mitosis (Fig. 2).
Fanconi anemia and p53: two guardians wrestling Improved understanding of genomic instability mechanisms in FA (Fig. 2) allows us to reconstruct the genome instability seen in FA cells. Another key tumor suppressor, p53, determines the fate of proliferating FA-deficient cells.

Chronic DNA damage activates the p53 response and promotes the $\mathrm{p} 53 / \mathrm{CHK} 1$-dependent $\mathrm{G}_{2} / \mathrm{M}$ cell cycle arrest [100-103], which decreases the pool of proliferating stem cells leading to bone marrow failure [100]. The proliferating cells develop progressive genomic instability as they undergo abnormal mitosis. The grossly aneuploid multinucleated cells generated through failed cell division are subject to further mutagenesis. This vicious cycle of genomic instability ultimately leads to either bone marrow failure (if the p53 cell cycle arrest prevails [100]) or cancer (if the p53 response is inactivated and genetically unstable cells are allowed to proliferate $[104,105])$.

Figure 2. Fanconi anemia (FA) signaling pathway guards the genome throughout the cell cycle

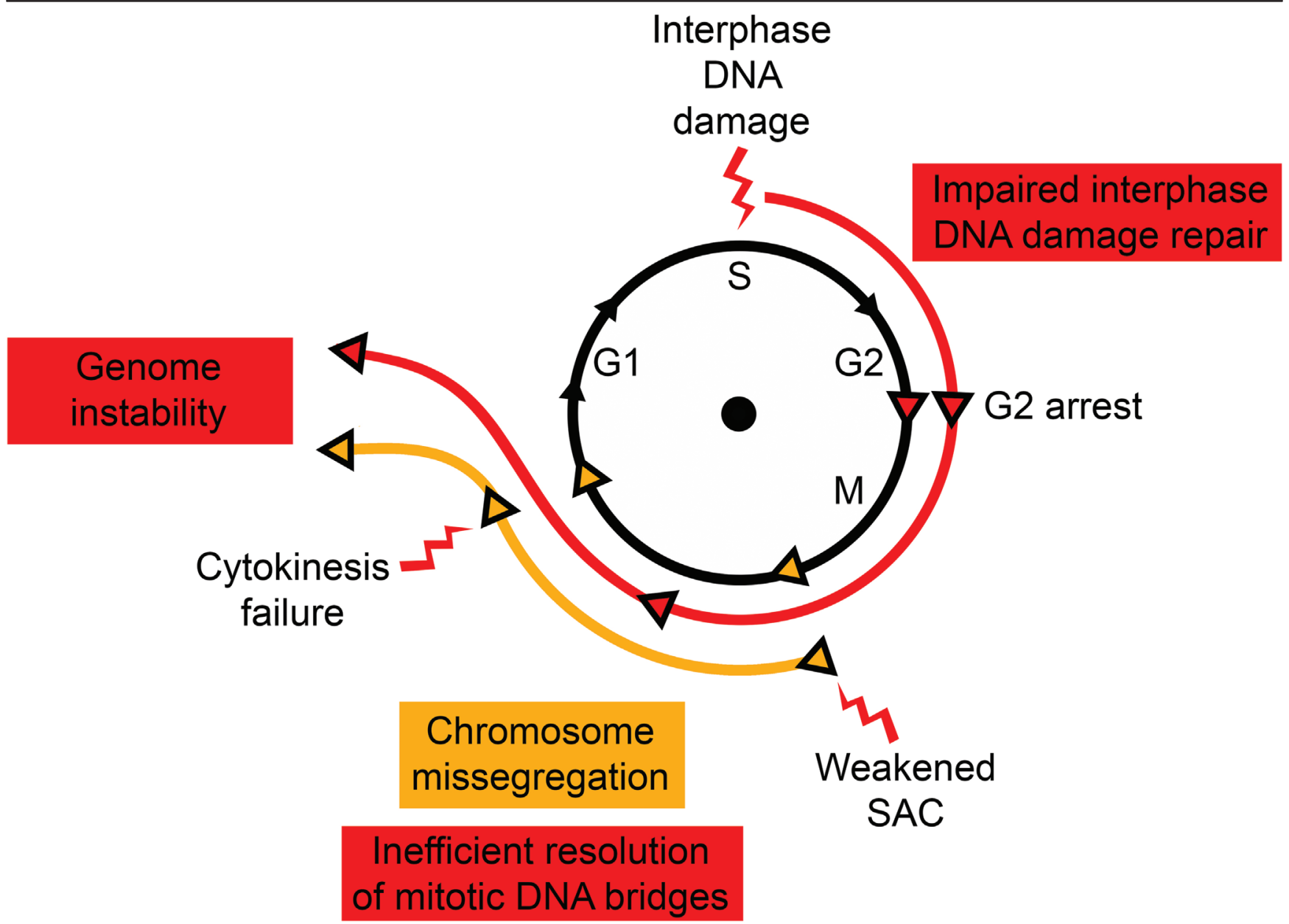

FA signaling prevents accumulation of DNA damages in interphase and ensures high-fidelity chromosome segregation in mitosis. Abbreviations: SAC, spindle assembly checkpoint. 


\section{Cytokine storm in Fanconi anemia}

FA-deficient cells express abnormally high levels of several pro-inflammatory cytokines, including tumor necrosis factor alpha (TNFo) and interferon gamma (IFN $\gamma$ ) $[106,107]$. It was confirmed that these essential mediators of inflammation are overexpressed in bone marrow of FA patients [108]. This hyperactivation of the cytokine network appears particularly detrimental to the survival of FA-deficient hematopoietic cells because loss of the FA signaling pathway renders hematopoietic cells dramatically hypersensitive to the growth-inhibitory and deathpromoting effects of the cytokine storm. Hematopoietic cells of the $\left.\mathrm{Fancc}^{-}\right|^{-}$mice are hypersensitive to the growthinhibitory effect of IFN $\gamma$ both in vitro $[109,110]$ and in vivo when IFN $\gamma$ is administered as continuous infusion $[111,112]$. This is at least partially mediated by increased activity of the Fas apoptotic programme, leading to the activation of caspases and death of hematopoietic cells [113-115].

Importantly, exposure to pro-inflammatory cytokines not only promotes the death of FA-deficient cells but also promotes the emergence of genomically unstable leukemic clones [116,117], highlighting the potential role of abnormal inflammatory response in leukemogenesis in FA. Since genetic correction of FANCC patient cells does not normalize expression of the essential p53 downstream gene (p21) [118], the inflammatory and p53-dependent pathways of hematopoietic cell loss and malignant transformation in FA are likely to be separate. Therefore, it is important to consider both signaling pathways as candidate therapeutic targets in future studies aiming to improve survival and decrease leukemogenic potential in FA patients.

\section{Summary}

Recent studies have provided exciting insights into the origins of genomic instability in FA. We now know that loss of FA signaling not only disrupts DNA damage recognition and repair in interphase [24] but also disrupts chromosome segregation in mitosis through weakening multiple cell division checkpoints [87,97-99]. These discoveries explain why loss of FA signaling promotes point mutations as well as gross chromosomal abnormalities. The signaling nodes connecting the FA signaling to other signal transduction pathways are being dissected through system biology studies. More detailed understanding of functional interactions between FA proteins, DNA damage kinases, and other signal transducers provides opportunities for a rational choice of therapeutic targets in FA-associated bone marrow failure and cancer. For example, FA-deficient cancer cells are hypersensitive to inhibition of the ataxia telangiectasia mutated (ATM) kinase [119], which is not surprising given the cross-talk between the DNA damage detection and the FA signaling pathway. Since cells deficient in homologous recombination-based DNA repair are hypersensitive to inhibition of the poly-(ADP-ribose) polymerase (PARP) pathway, small-molecule PARP inhibitors are being explored as targeted therapies of FA-deficient cancers [120]. However, the selected candidate targets should be carefully evaluated in preclinical studies to evaluate potential risks and benefits. For example, while silencing the $\mathrm{p} 53$ response may alleviate bone marrow failure in FA, it may also promote cancer $[100,104,105]$. Finally, better understanding of genotype-phenotype correlations in FA as well as optimizing clinical care of FA patients through clinical research will allow us to offer evidence-based interventions to this complex yet extremely rewarding group of patients.

\section{Abbreviations}

AML, acute myeloid leukemia; DEB, diepoxybutane; FA, Fanconi anemia; HPV, human papillomavirus; IFN $\gamma$, interferon gamma; NHEJ, non-homologous end joining; PARP, poly-(ADP-ribose) polymerase; SAC, spindle assembly checkpoint; SCC, squamous cell carcinoma.

\section{Disclosures}

The authors declare that they have no disclosures.

\section{Acknowledgments}

Research in Grzegorz Nalepa's laboratory is supported by the National Institutes of Health (NIH) K12 Indiana Pediatric Scientist Award and by the American Cancer Society ACSIRG Pilot Grant. D. Wade Clapp is supported by the NIH R01 CA138237-01 and CA155294-01 awards.

\section{References}

I. Alter BP, Giri N, Savage SA, Peters JA, Loud JT, Leathwood L, Carr AG, Greene $\mathrm{MH}$, Rosenberg PS: Malignancies and survival patterns in the National Cancer Institute inherited bone marrow failure syndromes cohort study. Br J Haematol 2010, I50:I79-88.

FlOOOPrime RECOMMENDED

2. Tamary H, Nishri D, Yacobovich J, Zilber R, Dgany O, Krasnov T, Aviner S, Stepensky P, Ravel-Vilk S, Bitan M, Kaplinsky C, Ben Barak A, Elhasid R, Kapelusnik J, Koren A, Levin C, Attias D, Laor R, Yaniv I, Rosenberg PS, Alter BP: Frequency and natural history of inherited bone marrow failure syndromes: the Israeli Inherited Bone Marrow Failure Registry. Haematologica 2010, 95:1300-7.

3. Rosenberg PS, Alter BP, Ebell W: Cancer risks in Fanconi anemia: findings from the German Fanconi Anemia Registry. Haematologica 2008, 93:5 II-7.

4. Alter BP: Cancer in Fanconi anemia, 1927-200I. Cancer 2003, 97:425-40.

\section{FlOOOPrime} RECOMMENDED

5. Rosenberg PS, Greene MH, Alter BP: Cancer incidence in persons with Fanconi anemia. Blood 2003, 10 I:822-6.

6. Bogliolo $M$, Schuster B, Stoepker C, Derkunt B, Su Y, Raams A, Trujillo JP, Minguillón J, Ramírez MJ, Pujol R, Casado JA, Baños R, 
Rio $P$, Knies $K$, Zúñiga $S$, Benítez J, Bueren JA, Jaspers NG], Schärer OD, Winter JP de, Schindler D, Surrallés J: Mutations in ERCC4, encoding the DNA-repair endonuclease XPF, cause Fanconi anemia. Am J Hum Genet 2013, 92:800-6.

\section{FlOOOPrime}

7. Kashiyama K, Nakazawa Y, Pilz DT, Guo C, Shimada M, Sasaki K, Fawcett H, Wing JF, Lewin SO, Carr L, Li T, Yoshiura K, Utani A, Hirano A, Yamashita S, Greenblatt D, Nardo T, Stefanini M, McGibbon D, Sarkany R, Fassihi H, Takahashi Y, Nagayama Y, Mitsutake N, Lehmann AR, Ogi T: Malfunction of nuclease ERCCI-XPF results in diverse clinical manifestations and causes Cockayne syndrome, xeroderma pigmentosum, and Fanconi anemia. Am J Hum Genet 2013, 92:807-19.

\section{FlOOOPrime}

\section{RECOMMENDED}

8. Kottemann MC, Smogorzewska A: Fanconi anaemia and the repair of Watson and Crick DNA crosslinks. Nature 2013, 493:356-63.

9. Rosenberg PS, Tamary H, Alter BP: How high are carrier frequencies of rare recessive syndromes? Contemporary estimates for Fanconi Anemia in the United States and Israel. Am J Med Genet A 20I I, 155:1877-83.

10. Shimamura A, Alter BP: Pathophysiology and management of inherited bone marrow failure syndromes. Blood Rev 2010, 24: $101-22$.

11. Zhu AX, D'Andrea AD, Sahani DV, Hasserjian RP: Case records of the Massachusetts General Hospital. Case 13-2006. A 50-year-old man with a painful bone mass and lesions in the liver. $N$ Engl J Med 2006, 354:1828-37.

12. Alfred R, Buchner-Daley L, Soyibo A, Brady-West D, Hardie R, McGrowder D: Late-onset Fanconi anemia in an AfricanCaribbean patient. J Natl Med Assoc 2010, 102:132-4.

13. Huck K, Hanenberg $H$, Gudowius S, Fenk R, Kalb R, Neveling K, Betz B, Niederacher D, Haas R, Göbel U, Kobbe G, Schindler D: Delayed diagnosis and complications of Fanconi anaemia at advanced age-a paradigm. Br J Haematol 2006, 133: I88-97.

14. Alter BP, Rosenberg PS: VACTERL-H Association and Fanconi Anemia. Mol Syndromol 2013, 4:87-93.

15. Neveling K, Endt D, Hoehn H, Schindler D: Genotype-phenotype correlations in Fanconi anemia. Mutat Res 2009, 668:73-9I.

\section{FlOOOPrime}

\section{RECOMMENDED}

16. Auerbach AD: Fanconi anemia and its diagnosis. Mutat Res 2009, 668:4-10.

17. Auerbach AD: Diagnosis of fanconi anemia by diepoxybutane analysis. Curr Protoc Hum Genet 2003, 37:8.7.I-8.7.I5 Chapter 8.

18. Kutler DI, Singh B, Satagopan J, Batish SD, Berwick M, Giampietro PF, Hanenberg $H$, Auerbach AD: A 20-year perspective on the International Fanconi Anemia Registry (IFAR). Blood 2003, 101:1249-56.

\section{FlOOOPrime \\ RECOMMENDED}

19. Howlett NG, Taniguchi T, Olson S, Cox B, Waisfisz Q, Die-Smulders C de, Persky N, Grompe M, Joenje H, Pals G, Ikeda H, Fox EA, D'Andrea AD: Biallelic inactivation of BRCA2 in Fanconi anemia. Science 2002, 297:606-9.

\section{FlOOOPrime}

\section{RECOMMENDED}

20. Reid S, Renwick A, Seal S, Baskcomb L, Barfoot R, Jayatilake $H$, Pritchard-Jones K, Stratton MR, Ridolfi-Lüthy A, Rahman N: Biallelic BRCA2 mutations are associated with multiple malignancies in childhood including familial Wilms tumour. J Med Genet 2005, 42:|47-5|.

21. Hirsch B, Shimamura A, Moreau L, Baldinger S, Hag-alshiekh M, Bostrom B, Sencer S, D'Andrea AD: Association of biallelic
BRCA2/FANCDI mutations with spontaneous chromosomal instability and solid tumors of childhood. Blood 2004, 103:2554-9.

22. Myers K, Davies SM, Harris RE, Spunt SL, Smolarek T, Zimmerman S, McMasters R, Wagner L, Mueller R, Auerbach AD, Mehta PA: The clinical phenotype of children with Fanconi anemia caused by biallelic FANCDI/BRCA2 mutations. Pediatr Blood Cancer 2012, 58:462-5.

23. Wagner JE, Tolar J, Levran O, Scholl T, Deffenbaugh A, Satagopan J, Ben-Porat L, Mah K, Batish SD, Kutler DI, MacMillan ML, Hanenberg H, Auerbach AD: Germline mutations in BRCA2: shared genetic susceptibility to breast cancer, early onset leukemia, and Fanconi anemia. Blood 2004, 103:3226-9.

\section{FIOOOPRime
RECOMMENDED}

24. D'Andrea AD: Susceptibility pathways in Fanconi's anemia and breast cancer. N Engl J Med 2010, 362:1909-19.

\section{FlOOOPrime
RECOMMENDED}

25. Scheckenbach K, Morgan M, Filger-Brillinger J, Sandmann M, Strimling B, Scheurlen W, Schindler D, Göbel U, Hanenberg H: Treatment of the bone marrow failure in Fanconi anemia patients with danazol. Blood Cells Mol. Dis 20I2, 48:I28-3I.

\section{FlOOOPrime}

26. Velazquez I, Alter BP: Androgens and liver tumors: Fanconi's anemia and non-Fanconi's conditions. Am J Hematol 2004, 77:257-67.

27. Tan $P$, Wagner JE, Auerbach AD, Defor TE, Slungaard A, MacMillan ML: Successful engraftment without radiation after fludarabine-based regimen in Fanconi anemia patients undergoing genotypically identical donor hematopoietic cell transplantation. Pediatr Blood Cancer 2006, 46:630-6.

28. Thakar MS, Kurre P, Storb R, Kletzel M, Frangoul H, Pulsipher MA, Leisenring W, Flowers MED, Sandmaier BM, Woolfrey A, Kiem H: Treatment of Fanconi anemia patients using fludarabine and low-dose TBI, followed by unrelated donor hematopoietic cell transplantation. Bone Marrow Transplant 20II, 46:539-44.

29. Kutler DI, Auerbach AD, Satagopan J, Giampietro PF, Batish SD, Huvos AG, Goberdhan A, Shah JP, Singh B: High incidence of head and neck squamous cell carcinoma in patients with Fanconi anemia. Arch Otolaryngol Head Neck Surg 2003, I29:106-I2.

\section{FlOOOPrime
RECOMMENDED}

30. Scheckenbach K, Wagenmann M, Freund M, Schipper J, Hanenberg H: Squamous cell carcinomas of the head and neck in Fanconi anemia: risk, prevention, therapy, and the need for guidelines. Klin Padiatr 2012, 224: 132-8.

\section{FlOOOPrime}

\section{RECOMMENDED}

31. Rosenberg PS, Socié G, Alter BP, Gluckman E: Risk of head and neck squamous cell cancer and death in patients with Fanconi anemia who did and did not receive transplants. Blood 2005, 105:67-73.

\section{FlOOOPrime
RECOMMENDED}

32. Alter BP, Giri N, Savage SA, Quint WGV, Koning MNC de, Schiffman M: Squamous cell carcinomas in patients with Fanconi anemia and dyskeratosis congenita: a search for human papillomavirus. Int J Cancer 2013, 133:1513-5.

33. Kutler DI, Wreesmann VB, Goberdhan A, Ben-Porat L, Satagopan J, Ngai I, Huvos AG, Giampietro P, Levran O, Pujara K, Diotti R, Carlson D, Huryn LA, Auerbach AD, Singh B: Human papillomavirus DNA and p53 polymorphisms in squamous cell carcinomas from Fanconi anemia patients. J Natl Cancer Inst 2003, 95:1718-2I.

34. Wajnrajch MP, Gertner JM, Huma Z, Popovic J, Lin K, Verlander PC, Batish SD, Giampietro PF, Davis JG, New MI, Auerbach AD: Evaluation of growth and hormonal status in patients referred 
to the International Fanconi Anemia Registry. Pediatrics 200I, 107:744-54.

35. Rose SR, Myers KC, Rutter MM, Mueller R, Khoury JC, Mehta PA, Harris RE, Davies SM: Endocrine phenotype of children and adults with Fanconi anemia. Pediatr Blood Cancer 2012, 59:690-6.

36. Kee $Y, D^{\prime}$ Andrea AD: Molecular pathogenesis and clinical management of Fanconi anemia. J Clin Invest 2012, I22:3799-806.

37. Kearney JA, Hay JL, Halpern L, Boulad F: Peritransplant psychiatric evaluation of patients with fanconi anemia. J Pediatr Hematol Oncol 20I2, 34:163-8.

38. MacMillan ML, Wagner JE: Haematopoeitic cell transplantation for Fanconi anaemia - when and how? Br J Haematol 2010, I49:14-2I.

39. Becker PS, Taylor JA, Trobridge GD, Zhao X, Beard BC, Chien S, Adair J, Kohn DB, Wagner JE, Shimamura A, Kiem H: Preclinical correction of human Fanconi anemia complementation group $\mathrm{A}$ bone marrow cells using a safety-modified lentiviral vector. Gene Ther 2010, 17:1244-52.

\section{FlOOOPrime}

\section{RECOMMENDED}

40. Río P, Meza NW, González-Murillo A, Navarro S, Alvarez L, Surrallés J, Castella M, Guenechea G, Segovia JC, Hanenberg H, Bueren JA: In vivo proliferation advantage of genetically corrected hematopoietic stem cells in a mouse model of Fanconi anemia FA-DI. Blood 2008, I I 2:4853-6I.

\section{FlOOOPrime \\ RECOMMENDED}

41. Tolar J, Adair JE, Antoniou M, Bartholomae CC, Becker PS, Blazar BR, Bueren J, Carroll T, Cavazzana-Calvo M, Clapp DW, Dalgleish R, Galy A, Gaspar HB, Hanenberg H, Kalle C von, Kiem H, Lindeman D, Naldini L, Navarro S, Renella R, Rio P, Sevilla J, Schmidt M, Verhoeyen E, Wagner JE, Williams DA, Thrasher AJ: Stem cell gene therapy for fanconi anemia: report from the Ist international Fanconi anemia gene therapy working group meeting. Mol Ther 201 I, 19:1 193-8.

42. Tolar J, Becker PS, Clapp DW, Hanenberg H, Heredia CD de, Kiem H, Navarro S, Qasba P, Rio P, Schmidt M, Sevilla J, Verhoeyen E, Thrasher AJ, Bueren J: Gene therapy for Fanconi anemia: one step closer to the clinic. Hum Gene Ther 20I2, 23:|4|-4.

43. Ciccia A, Elledge S): The DNA damage response: making it safe to play with knives. Mol. Cell 2010, 40:179-204.

44. Collis SJ, Ciccia A, Deans AJ, Horejsí Z, Martin JS, Maslen SL, Skehel JM, Elledge SJ, West SC, Boulton SJ: FANCM and FAAP24 function in ATR-mediated checkpoint signaling independently of the Fanconi anemia core complex. Mol Cell 2008, 32:3।3-24.

\section{FlOOOPrime}

45. Schwab RA, Blackford AN, Niedzwiedz W: ATR activation and replication fork restart are defective in FANCM-deficient cells. EMBO J 2010, 29:806-18.

46. Gong Z, Kim J, Leung CCY, Glover JNM, Chen J: BACHI/FANCJ acts with TopBPI and participates early in DNA replication checkpoint control. Mol Cell 2010, 37:438-46.

47. Andreassen PR, D'Andrea AD, Taniguchi T: ATR couples FANCD2 monoubiquitination to the DNA-damage response. Genes Dev 2004, I8:1958-63.

\section{FlOOOPrime}

\section{RECOMMENDED}

48. Collins NB, Wilson JB, Bush T, Thomashevski A, Roberts KJ, Jones NJ, Kupfer GM: ATR-dependent phosphorylation of FANCA on serine 1449 after DNA damage is important for FA pathway function. Blood 2009, I | 3:2181-90.

49. Wang X, Kennedy RD, Ray K, Stuckert P, Ellenberger T, D'Andrea AD: Chk I-mediated phosphorylation of FANCE is required for the Fanconi anemia/BRCA pathway. Mol Cell Biol 2007, 27:3098- 108.

50. Singh TR, Ali AM, Paramasivam M, Pradhan A, Wahengbam K, Seidman MM, Meetei AR: ATR-dependent phosphorylation of FANCM at serine 1045 is essential for FANCM functions. Cancer Res 2013, 73:4300-10.
5I. Singh TR, Saro D, Ali AM, Zheng X, Du C, Killen MW, Sachpatzidis A, Wahengbam K, Pierce AJ, Xiong Y, Sung P, Meetei AR: MHFIMHF2, a histone-fold-containing protein complex, participates in the Fanconi anemia pathway via FANCM. Mol Cell 2010, 37:879-86.

\section{FlOOOPrime} RECOMMENDED

52. Yan Z, Delannoy M, Ling C, Daee D, Osman F, Muniandy PA, Shen X, Oostra AB, Du H, Steltenpool J, Lin T, Schuster B, Décaillet C, Stasiak A, Stasiak AZ, Stone S, Hoatlin ME, Schindler D, Woodcock CL, Joenje H, Sen R, Winter JP de, Li L, Seidman MM, Whitby MC, Myung K, Constantinou A, Wang W: A histone-fold complex and FANCM form a conserved DNA-remodeling complex to maintain genome stability. Mol Cell 2010, 37:865-78.

\section{FIOOOPrime}

53. Machida YJ, Machida Y, Chen Y, Gurtan AM, Kupfer GM, D'Andrea AD, Dutta A: UBE2T is the E2 in the Fanconi anemia pathway and undergoes negative autoregulation. Mol Cell 2006, 23:589-96.

\section{FlOOOPrime}

\section{RECOMMENDED}

54. Meetei AR, Winter JP de, Medhurst AL, Wallisch M, Waisfisz Q, van de Vrugt HJ, Oostra AB, Yan Z, Ling C, Bishop CE, Hoatlin ME, Joenje $\mathrm{H}$, Wang $\mathrm{W}$ : A novel ubiquitin ligase is deficient in Fanconi anemia. Nat Genet 2003, 35:165-70.

\section{FlOOOPrime
RECOMMENDED}

55. Ishiai M, Kitao H, Smogorzewska A, Tomida J, Kinomura A, Uchida E, Saberi A, Kinoshita E, Kinoshita-Kikuta E, Koike T, Tashiro S, Elledge S], Takata M: FANCI phosphorylation functions as a molecular switch to turn on the Fanconi anemia pathway. Nat Struct Mol Biol 2008, I5: I 138-46.

\section{FlOOOPrime
RECOMMENDED}

56. Ho GPH, Margossian S, Taniguchi T, D’Andrea AD: Phosphorylation of FANCD2 on two novel sites is required for mitomycin C resistance. Mol Cell Biol 2006, 26:7005-I5.

\section{FlOOOPrime}

\section{RECOMMENDED}

57. Levran O, Attwooll C, Henry RT, Milton KL, Neveling K, Rio P, Batish SD, Kalb R, Velleuer E, Barral S, Ott J, Petrini J, Schindler D, Hanenberg $\mathrm{H}$, Auerbach AD: The BRCAl-interacting helicase BRIPI is deficient in Fanconi anemia. Nat Genet 2005, 37:931-3.

58. Rahman N, Seal S, Thompson D, Kelly P, Renwick A, Elliott A, Reid S, Spanova K, Barfoot R, Chagtai T, Jayatilake H, McGuffog L, Hanks S, Evans DG, Eccles D, Easton DF, Stratton MR: PALB2, which encodes a BRCA2-interacting protein, is a breast cancer susceptibility gene. Nat Genet 2007, 39:165-7.

59. Reid $S$, Schindler D, Hanenberg $H$, Barker K, Hanks S, Kalb R, Neveling K, Kelly P, Seal S, Freund M, Wurm M, Batish SD, Lach FP, Yetgin S, Neitzel H, Ariffin H, Tischkowitz M, Mathew CG, Auerbach $A D$, Rahman N: Biallelic mutations in PALB2 cause Fanconi anemia subtype FA-N and predispose to childhood cancer. Nat Genet 2007, 39:162-4.

60. Xia B, Dorsman JC, Ameziane N, Vries Y de, Rooimans MA, Sheng Q, Pals G, Errami A, Gluckman E, Llera J, Wang W, Livingston DM, Joenje H, Winter JP de: Fanconi anemia is associated with a defect in the BRCA2 partner PALB2. Nat Genet 2007, 39:159-61.

6I. Vaz F, Hanenberg H, Schuster B, Barker K, Wiek C, Erven V, Neveling K, Endt D, Kesterton I, Autore F, Fraternali F, Freund M, Hartmann L, Grimwade D, Roberts RG, Schaal H, Mohammed S, Rahman N, Schindler D, Mathew CG: Mutation of the RAD5 I C gene in a Fanconi anemia-like disorder. Nat Genet 2010, 42:406-9.

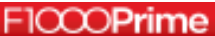


62. Karanam K, Kafri R, Loewer A, Lahav G: Quantitative live cell imaging reveals a gradual shift between DNA repair mechanisms and a maximal use of $\mathrm{HR}$ in mid $\mathrm{S}$ phase. Mol Cell 20I2, 47:320-9.

\section{FlOOOPRime}

63. Adamo A, Collis SJ, Adelman CA, Silva N, Horejsi Z, Ward JD, Martinez-Perez E, Boulton SJ, La Volpe A: Preventing nonhomologous end joining suppresses DNA repair defects of Fanconi anemia. Mol Cell 20I0, 39:25-35.

\section{FlOOOPrime} RECOMMENDED

64. Nijman SMB, Huang TT, Dirac AMG, Brummelkamp TR, Kerkhoven RM, D'Andrea AD, Bernards R: The deubiquitinating enzyme USPI regulates the Fanconi anemia pathway. Mol Cell 2005, I7:33|-9.

\section{FlOOOPrime} RECOMMENDED

65. Cohn MA, Kowal P, Yang K, Haas W, Huang TT, Gygi SP, D'Andrea AD: A UAFI-containing multisubunit protein complex regulates the Fanconi anemia pathway. Mol Cell 2007, 28:786-97.

\section{FlOOOPrime}

66. Kim JM, Parmar K, Huang M, Weinstock DM, Ruit CA, Kutok JL, D'Andrea AD: Inactivation of murine UspI results in genomic instability and a Fanconi anemia phenotype. Dev Cell 2009, 16:314-20.

\section{FlOOOPrime}

\section{RECOMMENDED}

67. Ishida R, Buchwald M: Susceptibility of Fanconi's anemia lymphoblasts to DNA-cross-linking and alkylating agents. Cancer Res 1982, 42:4000-6.

68. Cotta-Ramusino C, McDonald ER, Hurov K, Sowa ME, Harper JW, Elledge SJ: A DNA damage response screen identifies RHINO, a 9-I-I and TopBPI interacting protein required for ATR signaling. Science 20II, 332:1313-7.

\section{FlOOOPrime RECOMMENDED}

69. Helmrich A, Ballarino M, Tora $L$ : Collisions between replication and transcription complexes cause common fragile site instability at the longest human genes. Mol Cell 20II, 44:966-77.

\section{FlOOOPrime

RECOMMENDED

70. Bermejo R, Lai MS, Foiani M: Preventing replication stress to maintain genome stability: resolving conflicts between replication and transcription. Mol Cell 20I2, 45:7I0-8.

7I. Labib K, Piccoli G de: Surviving chromosome replication: the many roles of the S-phase checkpoint pathway. Philos Trans $R$ Soc Lond, B, Biol Sci 20I I, 366:3554-6I.

72. Branzei $D$, Foiani $M$ : Maintaining genome stability at the replication fork. Nat. Rev Mol Cell Biol 2010, I I:208-19.

73. Segurado M, Diffley JFX: Separate roles for the DNA damage checkpoint protein kinases in stabilizing DNA replication forks. Genes Dev 2008, 22:1816-27.

\section{FlOOOPrime}

\section{RECOMMENDED}

74. Pichierri P, Rosselli F: The DNA crosslink-induced S-phase checkpoint depends on ATR-CHKI and ATR-NBSI-FANCD2 pathways. EMBO J 2004, 23: I 178-87.

75. Sobeck A, Stone S, Costanzo V, Graaf B de, Reuter T, Winter I de, Wallisch M, Akkari Y, Olson S, Wang W, Joenje H, Christian JL, Lupardus PJ, Cimprich KA, Gautier J, Hoatlin ME: Fanconi anemia proteins are required to prevent accumulation of replicationassociated DNA double-strand breaks. Mol Cell Biol 2006, 26:425-37.
76. Pagano G, Korkina LG, Degan P, Del Principe D, Lindau-Shepard B, Zatterale A, Franceschi C: In vitro hypersensitivity to oxygen of Fanconi anemia (FA) cells is linked to ex vivo evidence for oxidative stress in FA homozygotes and heterozygotes. Blood 1997, 89: |||||-2.

77. Saito H, Hammond AT, Moses RE: Hypersensitivity to oxygen is a uniform and secondary defect in Fanconi anemia cells. Mutat Res 1993, 294:255-62.

78. Neubauer R, Neubauer A, Wölkart G, Schwarzenegger C, Lang B, Schmidt K, Russwurm M, Koesling D, Gorren ACF, Schrammel A, Mayer B: Potent inhibition of aldehyde dehydrogenase-2 by diphenyleneiodonium: focus on nitroglycerin bioactivation. Mol Pharmacol 2013, 84:407-14.

79. Perez-Miller S, Younus H, Vanam R, Chen C, Mochly-Rosen D, Hurley TD: Alda-I is an agonist and chemical chaperone for the common human aldehyde dehydrogenase 2 variant. Nat Struct Mol Biol 2010, 17:159-64.

80. O'Brien PJ, Siraki AG, Shangari N: Aldehyde sources, metabolism, molecular toxicity mechanisms, and possible effects on human health. Crit Rev Toxicol 2005, 35:609-62.

8I. Ridpath JR, Nakamura A, Tano K, Luke AM, Sonoda E, Arakawa H, Buerstedde J, Gillespie DAF, Sale JE, Yamazoe M, Bishop DK, Takata M, Takeda S, Watanabe M, Swenberg JA, Nakamura J: Cells deficient in the FANC/BRCA pathway are hypersensitive to plasma levels of formaldehyde. Cancer Res 2007, 67:1। I 17-22.

82. Langevin F, Crossan GP, Rosado IV, Arends MJ, Patel KJ: Fancd2 counteracts the toxic effects of naturally produced aldehydes in mice. Nature 201 I, 475:53-8.

\section{FlOOOPRime
RECOMMENDED}

83. Zhang Q, Marquez-Loza L, Eaton L, Duncan AW, Goldman DC, Anur P, Watanabe-Smith K, Rathbun RK, Fleming WH, Bagby GC, Grompe M: Fancd2-I- mice have hematopoietic defects that can be partially corrected by resveratrol. Blood 2010, I 16:5140-8.

84. Garaycoechea JI, Crossan GP, Langevin F, Daly M, Arends MJ, Patel KJ: Genotoxic consequences of endogenous aldehydes on mouse haematopoietic stem cell function. Nature 2012, 489:57I-5.

\section{FlOOOPrime}

85. Gordon DJ, Resio B, Pellman D: Causes and consequences of aneuploidy in cancer. Nat Rev Genet 2012, 13:189-203.

86. Musacchio A, Salmon ED: The spindle-assembly checkpoint in space and time. Nat Rev Mol Cell Biol 2007, 8:379-93.

87. Nalepa G, Enzor R, Sun Z, Marchal C, Park S, Yang Y, Tedeschi L, Kelich S, Hanenberg H, Clapp DW: Fanconi anemia signaling network regulates the spindle assembly checkpoint. J Clin Invest 2013, I23:3839-47.

88. Mi J, Qiao F, Wilson JB, High AA, Schroeder MJ, Stukenberg PT, Moss A, Shabanowitz J, Hunt DF, Jones NJ, Kupfer GM: FANCG is phosphorylated at serines $\mathbf{3 8 3}$ and $\mathbf{3 8 7}$ during mitosis. Mol Cell Biol 2004, 24:8576-85.

89. Kupfer GM, Yamashita T, Naf D, Suliman A, Asano S, D'Andrea AD: The Fanconi anemia polypeptide, FAC, binds to the cyclindependent kinase, cdc2. Blood 1997, 90:1047-54

90. Nalepa G, Enzor R, Sun Z, Marchal C, Park S, Yang Y, Tedeschi L, Kelich S, Hanenberg $\mathrm{H}$, Clapp DW: Fanconi anemia signaling network regulates the spindle assembly checkpoint. J Clin Invest 2013, 123:3839-47.

91. Zou J, Tian F, Li J, Pickner W, Long M, Rezvani K, Wang H, Zhang D: FancJ regulates interstrand crosslinker induced centrosome amplification through the activation of polo-like kinase I. Biol Open 20I3, 2:1022-3|.

\section{FlOOOPrime}

\section{RECOMMENDED}

92. Kim S, Hwang SK, Lee M, Kwak H, Son K, Yang J, Kim SH, Lee C: Fanconi anemia complementation group A (FANCA) 
localizes to centrosomes and functions in the maintenance of centrosome integrity. Int J Biochem Cell Biol 20I3, 45:1953-6I.

\section{FIOOOPrime}

93. Lee $H$, Trainer AH, Friedman LS, Thistlethwaite FC, Evans MJ, Ponder BA, Venkitaraman AR: Mitotic checkpoint inactivation fosters transformation in cells lacking the breast cancer susceptibility gene, Brca2. Mol Cell 1999, 4:I-10.

94. Nakanishi A, Han X, Saito H, Taguchi K, Ohta Y, Imajoh-Ohmi S, Miki $Y$ : Interference with BRCA2, which localizes to the centrosome during $\mathbf{S}$ and early $\mathbf{M}$ phase, leads to abnormal nuclear division. Biochem Biophys Res Commun 2007, 355:34-40.

95. Tutt A, Gabriel A, Bertwistle D, Connor F, Paterson H, Peacock J, Ross G, Ashworth A: Absence of Brca2 causes genome instability by chromosome breakage and loss associated with centrosome amplification. Curr Biol 1999, 9: I 107-10.

96. Ganem NJ, Godinho SA, Pellman D: A mechanism linking extra centrosomes to chromosomal instability. Nature 2009, 460:278-82.

\section{FlOOOPrime \\ RECOMMENDED}

97. Naim V, Rosselli F: The FANC pathway and BLM collaborate during mitosis to prevent micro-nucleation and chromosome abnormalities. Nat Cell Biol 2009, I I:76I-8.

98. Chan KL, Palmai-Pallag T, Ying S, Hickson ID: Replication stress induces sister-chromatid bridging at fragile site loci in mitosis. Nat Cell Biol 2009, I I:753-60.

\section{FIOOOPrime
RECOMMENDED}

99. Vinciguerra P, Godinho SA, Parmar K, Pellman D, D'Andrea AD: Cytokinesis failure occurs in Fanconi anemia pathwaydeficient murine and human bone marrow hematopoietic cells. J Clin Invest 2010, I 20:3834-42.

100. Ceccaldi R, Parmar K, Mouly E, Delord M, Kim JM, Regairaz M, Pla M, Vasquez N, Zhang Q, Pondarre C, Peffault de Latour R, Gluckman E, Cavazzana-Calvo M, Leblanc T, Larghero J, Grompe M, Socié G, D'Andrea AD, Soulier J: Bone marrow failure in Fanconi anemia is triggered by an exacerbated p53/p2I DNA damage response that impairs hematopoietic stem and progenitor cells. Cell Stem Cell 2012, I I:36-49.

\section{FlOOOPrime} RECOMMENDED

I0I. Freie BW, Ciccone SLM, Li X, Plett PA, Orschell CM, Srour EF, Hanenberg H, Schindler D, Lee S, Clapp DW: A role for the Fanconi anemia $C$ protein in maintaining the DNA damageinduced G2 checkpoint. J Biol Chem 2004, 279:50986-93.

102. Guervilly J, Macé-Aimé G, Rosselli F: Loss of CHKI function impedes DNA damage-induced FANCD2 monoubiquitination but normalizes the abnormal $\mathbf{G 2}$ arrest in Fanconi anemia. Hum Mol Genet 2008, I7:679-89.

103. Zhu W, Dutta A: An ATR- and BRCAl-mediated Fanconi anemia pathway is required for activating the $\mathrm{G} 2 / \mathrm{M}$ checkpoint and DNA damage repair upon rereplication. Mol Cell Biol 2006, 26:460I-II.

104. Ceccaldi R, Briot D, Larghero J, Vasquez N, Dubois d'Enghien C, Chamousset D, Noguera M, Waisfisz Q, Hermine O, Pondarre C, Leblanc T, Gluckman E, Joenje H, Stoppa-Lyonnet D, Socié G, Soulier J: Spontaneous abrogation of the G2DNA damage checkpoint has clinical benefits but promotes leukemogenesis in Fanconi anemia patients. J Clin Invest 201 I, I 2 I: I84-94.

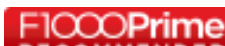

\section{RECOMMENDED}

105. Freie B, Li X, Ciccone SLM, Nawa K, Cooper S, Vogelweid C, Schantz L, Haneline LS, Orazi A, Broxmeyer HE, Lee S, Clapp DW:
Fanconi anemia type $\mathbf{C}$ and p53 cooperate in apoptosis and tumorigenesis. Blood 2003, 102:4146-52.

106. Vanderwerf SM, Svahn J, Olson S, Rathbun RK, Harrington C, Yates J, Keeble W, Anderson DC, Anur P, Pereira NF, Pilonetto DV, Pasquini R, Bagby GC: TLR8-dependent TNF-(alpha) overexpression in Fanconi anemia group C cells. Blood 2009, I I 4:5290-8.

107. Briot D, Macé-Aimé G, Subra F, Rosselli F: Aberrant activation of stress-response pathways leads to TNF-alpha oversecretion in Fanconi anemia. Blood 2008, I I I:1913-23.

108. Dufour C, Corcione A, Svahn J, Haupt R, Poggi V, Béka'ssy AN, Scimè $R$, Pistorio $A$, Pistoia $V$ : TNF-alpha and IFN-gamma are overexpressed in the bone marrow of Fanconi anemia patients and TNF-alpha suppresses erythropoiesis in vitro. Blood 2003, 102:2053-9.

109. Pang Q, Keeble W, Christianson TA, Faulkner GR, Bagby GC: FANCC interacts with $\mathrm{Hsp} 70$ to protect hematopoietic cells from IFN-gamma/TNF-alpha-mediated cytotoxicity. EMBO J 200I, 20:4478-89.

I I0. Haneline LS, Broxmeyer HE, Cooper S, Hangoc G, Carreau M, Buchwald M, Clapp DW: Multiple inhibitory cytokines induce deregulated progenitor growth and apoptosis in hematopoietic cells from Fac-/- mice. Blood 1998, 91:4092-8.

III. Li X, Yang Y, Yuan J, Hong P, Freie B, Orazi A, Haneline LS, Clapp DW: Continuous in vivo infusion of interferon-gamma (IFN-gamma) preferentially reduces myeloid progenitor numbers and enhances engraftment of syngeneic wild-type cells in Fancc-/- mice. Blood 2004, I 04: I204-9.

I 12. Si Y, Ciccone S, Yang F, Yuan J, Zeng D, Chen S, van de Vrugt HJ, Critser J, Arwert F, Haneline LS, Clapp DW: Continuous in vivo infusion of interferon-gamma (IFN-gamma) enhances engraftment of syngeneic wild-type cells in Fanca-/- and Fancg-/- mice. Blood 2006, 108:4283-7.

II3. Rathbun RK, Christianson TA, Faulkner GR, Jones G, Keeble W, O'Dwyer M, Bagby GC: Interferon-gamma-induced apoptotic responses of Fanconi anemia group $\mathbf{C}$ hematopoietic progenitor cells involve caspase 8-dependent activation of caspase 3 family members. Blood 2000, 96:4204-II.

I 4. Rathbun RK, Faulkner GR, Ostroski MH, Christianson TA, Hughes G, Jones G, Cahn R, Maziarz R, Royle G, Keeble W, Heinrich MC, Grompe M, Tower PA, Bagby GC: Inactivation of the Fanconi anemia group $C$ gene augments interferon-gamma-induced apoptotic responses in hematopoietic cells. Blood 1997, 90:974-85.

II5. Ridet A, Guillouf C, Duchaud E, Cundari E, Fiore M, Moustacchi E, Rosselli F: Deregulated apoptosis is a hallmark of the Fanconi anemia syndrome. Cancer Res 1997, 57:1722-30.

I 16. Li X, Le Beau MM, Ciccone S, Yang F, Freie B, Chen S, Yuan J, Hong P, Orazi A, Haneline LS, Clapp DW: Ex vivo culture of Fancc-/stem/progenitor cells predisposes cells to undergo apoptosis, and surviving stem/progenitor cells display cytogenetic abnormalities and an increased risk of malignancy. Blood 2005, | 05:3465-7|.

117. Li J, Sejas DP, Zhang X, Qiu Y, Nattamai KJ, Rani R, Rathbun KR, Geiger H, Williams DA, Bagby GC, Pang Q: TNF-alpha induces leukemic clonal evolution ex vivo in Fanconi anemia group C murine stem cells. J Clin Invest 2007, I I 7:3283-95.

I 18. Fagerlie SR, Diaz J, Christianson TA, McCartan K, Keeble W, Faulkner GR, Bagby GC: Functional correction of FA-C cells with FANCC suppresses the expression of interferon gamma-inducible genes. Blood 200I, 97:3017-24.

I19. Kennedy RD, Chen CC, Stuckert P, Archila EM, La Vega MA de, Moreau LA, Shimamura A, D'Andrea AD: Fanconi anemia pathway-deficient tumor cells are hypersensitive to inhibition of ataxia telangiectasia mutated. J Clin Invest 2007, I I 7:|440-9.

120. Bryant HE, Schultz N, Thomas HD, Parker KM, Flower D, Lopez E, Kyle S, Meuth M, Curtin NJ, Helleday T: Specific killing of BRCA2deficient tumours with inhibitors of poly(ADP-ribose) polymerase. Nature 2005, 434:913-7. 